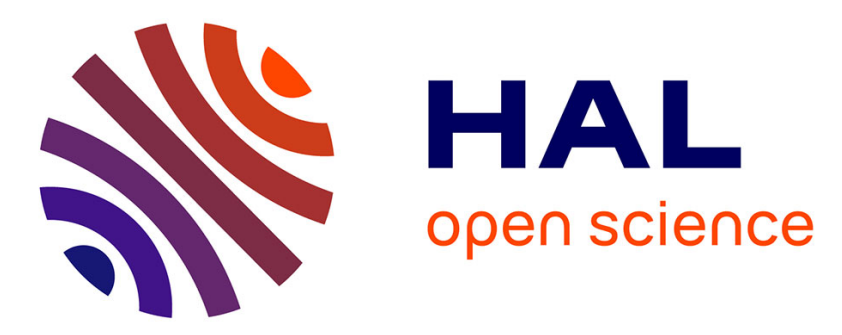

\title{
Diurnal expression of SAR11 proteorhodopsin and 16S rRNA genes in coastal North Atlantic waters
}

Raphaël Lami, David L. Kirchman

\section{To cite this version:}

Raphaël Lami, David L. Kirchman. Diurnal expression of SAR11 proteorhodopsin and 16S rRNA genes in coastal North Atlantic waters. Aquatic Microbial Ecology, 2014, 73 (3), pp.185-194. 10.3354/ame01716 . hal-02906988

\section{HAL Id: hal-02906988 \\ https://hal.sorbonne-universite.fr/hal-02906988}

Submitted on 27 Jul 2020

HAL is a multi-disciplinary open access archive for the deposit and dissemination of scientific research documents, whether they are published or not. The documents may come from teaching and research institutions in France or abroad, or from public or private research centers.
L'archive ouverte pluridisciplinaire HAL, est destinée au dépôt et à la diffusion de documents scientifiques de niveau recherche, publiés ou non, émanant des établissements d'enseignement et de recherche français ou étrangers, des laboratoires publics ou privés. 


\title{
Diurnal expression of SAR11 proteorhodopsin and 16S rRNA genes in coastal North Atlantic waters
}

\author{
Raphaël Lami ${ }^{1,2,3, *}$, David L. Kirchman ${ }^{1}$ \\ ${ }^{1}$ University of Delaware, School of Marine Science and Policy, Lewes, Delaware 19958, USA \\ ${ }^{2}$ Sorbonne Universités, UPMC Univ Paris 06, USR 3579, LBBM, Observatoire Océanologique, 66650 Banyuls-sur-Mer, France \\ ${ }^{3}$ CNRS, USR 3579, LBBM, Observatoire Océanologique, 66650 Banyuls-sur-Mer, France
}

\begin{abstract}
Proteorhodopsins (PR) are phylogenetically widespread and highly expressed proton pumps in marine bacterial communities, including in the SAR11 clade, one of the most common clades in the oceans. The relationships between PR expression, light and cell activity remain unclear, especially in natural environments. We examined these relationships during 3 diurnal studies in spring, summer and fall in Delaware coastal waters. The abundance of genes and transcripts of SAR11 PR, SAR11 16S rRNA and total bacterial 16S rRNA were monitored using a quantitative PCR approach. We found that the expression of SAR11 PR was 2.5-fold higher during the day than at night. However, SAR11 16S rRNA levels remained constant during the day and night on all cruises, suggesting that the growth-related activity of SAR11 was not directly affected by sunlight. There was a tight correlation between expression of PR in SAR11 and photosynthetically active radiation, but not with other environmental parameters. Our data support the hypothesis that light affects PR expression by SAR11 populations, but the energy from PR appears to contribute relatively little to supporting bacterial growth-related activity in marine waters.
\end{abstract}

KEY WORDS: Marine bacteria $\cdot \mathrm{SAR} 11 \cdot$ Proteorhodopsin $\cdot$ Quantitative PCR Resale or republication not permitted without written consent of the publisher

\section{INTRODUCTION}

Proteorhodopsins (PR) constitute a major group of proteins that are expressed in the marine environment. Since their discovery in 2000 (Béjà et al. 2000), several studies have revealed their broad phylogenetic and geographic distribution (de la Torre et al. 2003, Finkel et al. 2013) and their high abundance in marine waters (Venter et al. 2004, Rusch et al. 2007, Campbell et al. 2008, Finkel et al. 2013). These data suggest the importance of this protein in bacterial physiology and for potentially regulating energy fluxes in the oceans.

The physiological roles of PR are currently being investigated. Although some rhodopsins in marine microbes may be light sensors (Fuhrman et al. 2008), experimental studies and sequence analyses have indicated that PR are proton pumps, enabling photophosphorylation and cell motility (Walter et al. 2007). Recent studies have found that PR promotes the survival of marine bacteria during starvation (Gómez Consarnau et al. 2010, Steindler et al. 2011). Also, Wang et al. (2012) showed that PR can be expressed in vibrios under respiratory stress, while Feng et al. (2013) found higher PR expression in the flavobacterium Psychroflexus torquis when grown in salinities below or above optimal levels. Results from these previous studies are consistent with the hypothesis that light provides additional energy for PR-containing bacteria starved of organic carbon or stressed by low nutrient concentrations or other environmental properties.

However, the effects of light on the growth-related activity of PR-containing bacteria remain unclear. 
Light does not affect the growth of a cultivated representative of the SAR11 clade (Giovannoni et al. 2005, Steindler et al. 2011), and the gammaproteobacterium SAR92 HTCC2207 and the flavobacterium Dokdonia PRO95 grew equally well under dark and light (Stingl et al. 2007, Riedel et al. 2010). In contrast, Dokdonia MED134 has been shown to grow faster with light (Gómez-Consarnau et al. 2007, Kimura et al. 2011), and salinity-stressed $P$. torquis also grows faster with light, although there was no effect when it was grown under organic carbon limitation (Feng et al. 2013). In one of the few studies with natural communities, light did affect the growth of SAR11 bacteria in microcosms exposed to artificial light-dark cycles (Lami et al. 2009a). Also, the fraction of cells using leucine in the light was $25 \%$ higher for SAR11 bacteria than for the total bacterial community in Delaware Bay, although the effect was not consistently seen (Straza \& Kirchman 2011). Other studies have seen either no effect or even inhibition by light of the activity of natural microbial communities with potential PR-containing bacteria (Michelou et al. 2007, Straza \& Kirchman 2011, Ruiz-González et al. 2012a,b).

A few contradictory studies have examined the effects of light on PR expression. Light significantly induces PR expression in Dokdonia MED134 cells grown in pure culture (Gómez-Consarnau et al. 2007, Kimura et al. 2011), while Steindler et al. (2011) found PR expression by a Candidatus Pelagibacter strain (HTCC1062) to be 2-fold higher in the dark compared with the light, although mass spectrometry data indicate that the PR protein is present in the light and dark (Giovannoni et al. 2005). In contrast, PR transcript levels were similar in light and dark for Dokdonia PRO95 (Riedel et al. 2010). Interestingly, Akram et al. (2013) found that expression of PR was higher at the transition from the exponential growth phase to the stationary phase for Vibrio sp. AND4. These authors argued that nutrients, not light exposure, regulated PR expression by this bacterium. During a microcosm experiment with natural microbial communities, light-dependent PR expression was observed in SAR11 and flavobacterial groups (Lami et al. 2009a), and PR transcripts were more abundant during the day than at night in the North Pacific Ocean (Poretsky et al. 2009), but not in coastal waters of northern California (Ottesen et al. 2013). These data indicate the need to better characterize the relationships between light, other environmental conditions and PR expression. In particular, it is not clear whether light stimulates PR expression by natural marine communities and whether this expression is tied to enhanced growth-related activity by PRcontaining bacteria.

In this study, we examined the expression of PR and 16S rRNA by bacteria in the SAR11 clade under natural day-night cycles during 3 cruises in Delaware coastal waters. SAR11 bacteria are often the most abundant taxa in marine systems (Morris et al. 2002), including Delaware coastal waters (Campbell et al. 2011). We used a quantitative PCR (qPCR) approach to examine the genes and transcripts of PR and 16S rRNA for SAR11 and the total bacterial community. The total diversity of $16 \mathrm{~S}$ rRNA genes was also determined by 454 pyrosequencing to explore overall changes in the bacterial communities during the 3 diurnal studies. We observed light-dependent relative expression of SAR11 PR during all cruises, but light did not seem to directly affect activity of SAR11 bacteria.

\section{MATERIALS AND METHODS}

Water samples were collected aboard the R/V 'Hugh R. Sharp' from Delaware coastal waters (38 $50.935^{\prime} \mathrm{N}$, $75^{\circ} 6.456^{\prime} \mathrm{W}$ ) at $1 \mathrm{~m}$ depth using a rosette of Niskin bottles mounted on a CTD profiler. The light sensor was a Biospherical PNF-210 radiometer. The cruise dates were 3-4 May 2007, 20-21 September 2007 and 8-9 September 2008. Samples were taken about every $4 \mathrm{~h}$. All samples were processed immediately onboard. A total of $1 \mathrm{l}$ was filtered for each sample, under reduced light intensities overnight to minimize the effects of filtration on gene expression. All data are expressed as a function of solar time, which was $2 \mathrm{~h}$ before local time during these cruises.

\section{Environmental parameters and nucleic acid extraction}

Total prokaryote abundance, bacterial production and chlorophyll a ( $\mathrm{chl}$ a) were measured following previously described protocols (Cottrell et al. 2006). For pyrosequencing and qPCR analyses, all water samples were pre-filtered through $0.8 \mu \mathrm{m}$ polycarbonate filters to minimize the presence of eukaryotic DNA, and the $<0.8 \mu \mathrm{m}$ size fraction was collected on $0.22 \mu \mathrm{m}$ Durapore filters. Filters were then placed in $2 \%$ N-cetyl N,N,N-trimethylammonium bromide and stored onboard at $80^{\circ} \mathrm{C}$. Total DNA was extracted using standard protocols (Dempster et al. 1999) and quantified via a standard picogreen assay (Invitrogen) on a POLARstar Optima fluorometer (BMG 
Labtech). Total RNA was co-extracted with DNA and isolated using the following mix (Turbo DNA-free Kit, Ambion): 0.5 units of DNase I per $100 \mathrm{ng}$ of total nucleic acids with $1 \mu$ of $10 \times$ buffer (Ambion) (30 min, twice, $37^{\circ} \mathrm{C}$ ). Total RNA was quantified via a ribogreen assay (Invitrogen) on the POLARstar Optima fluorometer. DNA removal from RNA samples was confirmed by PCR amplification without the reverse transcription step, following the PCR conditions described below. No amplification was detected in these controls.

\section{Quantification of PR gene and transcript abundance}

SAR11 PR genes and transcripts were targeted by qPCR. The SAR11 PR primers and PCR conditions were the same as those described in Lami et al. (2009a). One PR-containing plasmid was used as a positive control to establish standard curves in the qPCR assays. This PR gene, similar to the one in the targeted SAR11 populations (data not shown), was isolated from environmental clones (Qiaprep Kit, Qiagen) and linearized with PstI (Invitrogen). Standard reactions with linearized plasmid contained approximately $10^{1}$ to $10^{6}$ copies per reaction. All standard curves were linear within the ranges tested.

Quantitative PCR was performed in triplicate or quadruplicate with $1 \mu \mathrm{l}$ of diluted DNA $\left(0.1 \mathrm{ng}^{\mathrm{N}} \mathrm{l}^{-1}\right)$ or $1 \mu \mathrm{l}$ of diluted RNA $\left(0.05 \mathrm{ng}^{-1}\right)$ in a final volume of $12.5 \mu \mathrm{l}$ using the Stratagene SYBR green mix with an ABI 7500 (Applied Biosystems). The PCR conditions were an initial denaturation step at $95^{\circ} \mathrm{C}$ (10 min for qPCR, 5 min for real-time qPCR), followed by 30 to 40 cycles of amplification at $95^{\circ} \mathrm{C}$ for $15 \mathrm{~s}$, the indicated annealing temperature for $45 \mathrm{~s}$, and $72^{\circ} \mathrm{C}$ for $45 \mathrm{~s}$, with a final dissociation step. No reverse transcription was performed during the $\mathrm{qPCR}$ reactions. For real-time $\mathrm{qPCR}$, an additional step was added before the denaturation step $\left(40^{\circ} \mathrm{C}, 1 \mathrm{~min}\right)$. Final primer concentrations were $0.2 \mu \mathrm{M}$. Only single peaks were observed in the dissociation curves for both the standards and samples, indicating specific amplification with each set of primers. Amplification efficiencies were between 92 and $103 \%$, and no inhibition was detected when a known quantity of standard was added to each sample (data not shown). The detection limit of qPCR assays was about 50 copies of genes or transcripts per ml. The specificity of the SAR11 PR primers has been previously confirmed, as discussed in more detail by Campbell et al. (2008).

\section{Sequence analysis of 16S rRNA genes}

All 16S rRNA genes were pyrosequenced on a Roche 454 FLX instrument (Research and Testing Laboratory) using a mixture of Hot Start and HotStar high-fidelity Taq polymerases, which generated amplicons of 250 to $550 \mathrm{bp}$ starting from position 27 (Escherichia coli 16S rRNA number). Sequences were run through AmpliconNoise and Perseus (Quince et al. 2009) to remove noise and chimeras from the original SFF files. The 16S rRNA sequences were de-multiplexed and quality filtered, and homopolymers were removed using QIIME (Caporaso et al. 2010). QIIME was also used to calculate alphaand beta-diversity indices (Caporaso et al. 2010). Sequences are available at the European Nucleotide Archive, accession number ERP003436/PRJEB4174.

\section{RESULTS}

\section{Environmental parameters and microbial diversity}

Salinity was relatively constant during the 3 cruises, varying between 30.4 and 31.6 PSU (Table 1). Chl a concentrations were low in May 2007 (1.61 \pm 0.03

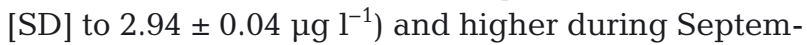
ber 2007 and $2008\left(8.4 \pm 0.1\right.$ to $\left.15.6 \pm 0.7 \mu \mathrm{g} \mathrm{l}^{-1}\right)$. Bacterial abundances varied overall between $1.56 \times 10^{6} \pm$ $5.68 \times 10^{5}$ and $6.9 \times 10^{6} \pm 0.2 \times 10^{6} \mathrm{cells} \mathrm{ml}^{-1}$ (Table 1 ). Bacterial production (leucine incorporation) was lower in May 2007, varying from 16 to $54 \mathrm{pM} \mathrm{h}^{-1}$, than in September 2007, when it varied between 86 and $151 \mathrm{pM} \mathrm{h}^{-1}$ (Fig. 1). Production was highest in September 2008 (between 116 and $397 \mathrm{pM} \mathrm{h}^{-1}$ ).

Light penetration in the water column, as indicated by the attenuation coefficient, varied from 0.66 to $0.21 \mathrm{~m}^{-1}$ during May 2007, from 0.6 to $0.54 \mathrm{~m}^{-1}$ during September 2007, and from 0.73 to $0.63 \mathrm{~m}^{-1}$ during September 2008. Photosynthetically active radiation (PAR) was between 160 and $2050 \mu \mathrm{mol} \mathrm{m} \mathrm{m}^{-2} \mathrm{~s}^{-1}$ in May and between 110 and $2990 \mu \mathrm{mol} \mathrm{m} \mathrm{m}^{-2} \mathrm{~s}^{-1}$ during the September cruises (Table 1).

UPGMA clustering revealed 3 groups of 16S rRNA gene pyrosequences (97\% similarity) representing the entire bacterial communities sampled by the 3 cruises. 16S rRNA genes varied more between the cruises than during one cruise (Fig. 2). Similarly, there was no significant correlation between 16S rRNA diversity and the tides (data not shown).

The SAR11 clade dominated the community composition during all cruises, making up 32 to $37 \%$ of the total sequences (Table 2). The SAR86 clade was 
Table 1. Selected biogeochemical parameters during the 3 cruises in Delaware coastal waters. PAR = photosynthetically active radiation. Inc. $=$ incorporation, Abund.$=$ Abundance, Atten.$=$ Attenuation

\begin{tabular}{|c|c|c|c|c|c|c|c|c|c|c|}
\hline $\begin{array}{l}\text { Cruise } \\
\text { Solar time (h) }\end{array}$ & $\begin{array}{l}\text { Temp. } \\
\left({ }^{\circ} \mathrm{C}\right)\end{array}$ & $\begin{array}{l}\text { Salinity } \\
\text { (PSU) }\end{array}$ & 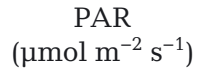 & $\begin{array}{l}\text { Atten. } \\
\left(\mathrm{m}^{-1}\right)\end{array}$ & $\begin{array}{l}\text { Chl a } \\
\qquad(\mu \mathrm{g}\end{array}$ & ${ }_{-1}^{\mathrm{SD}}$ & $\begin{array}{l}\text { Abund. } \\
\left(10^{6} \text { cells }\right.\end{array}$ & $\begin{array}{l}\mathrm{SD} \\
\left.\mathrm{ml}^{-1}\right)\end{array}$ & \multicolumn{2}{|c|}{$\begin{array}{c}\text { Leucine inc. SD } \\
\qquad\left(\mathrm{pM} \mathrm{h}^{-1}\right)\end{array}$} \\
\hline \multicolumn{11}{|l|}{ May 2007} \\
\hline 09:00 & 11.7 & 31.2 & 1460 & 0.66 & 2.92 & 0.04 & 1.9 & 0.5 & 20.3 & 2.3 \\
\hline $13: 00$ & 12.1 & 31.3 & 1870 & 0.42 & 2.43 & 0.09 & 1.6 & 0.5 & 33.6 & 7.3 \\
\hline $17: 00$ & 12.2 & 31.4 & 160 & 0.39 & 1.62 & 0.03 & 2.0 & 0.5 & 16.0 & 9.5 \\
\hline $21: 00$ & 12.3 & 31.0 & Night & Night & 1.69 & 0.05 & 2.5 & 0.6 & 53.7 & 3.6 \\
\hline 01:00 & 11.8 & 31.4 & Night & Night & 2.07 & 0.10 & 3.9 & 0.5 & 37.1 & 2.9 \\
\hline 05:00 & 11.8 & 31.3 & 240 & 0.43 & 2.31 & 0.05 & 3.0 & 0.1 & 31.1 & 5.1 \\
\hline 09:00 & 11.8 & 31.5 & 2050 & 0.21 & 1.95 & 0.05 & 2.3 & 0.4 & 31.1 & 2.2 \\
\hline \multicolumn{11}{|l|}{ Sep 2007} \\
\hline 06:30 & 21.3 & 31.4 & 110 & Night & 8.41 & 0.14 & 3.7 & 0.7 & 150.7 & 7.6 \\
\hline $10: 30$ & 21.2 & 31.5 & 224 & 0.6 & 9.63 & 0.10 & 4.2 & 0.5 & 97.9 & 4.7 \\
\hline $14: 30$ & 21.8 & 31.5 & 1900 & 0.59 & 8.23 & 0.92 & 3.7 & 0.7 & 128.0 & 11.9 \\
\hline $18: 30$ & 21.6 & 31.6 & Night & Night & 7.25 & 0.33 & 4.0 & 0.4 & 106.2 & 17.6 \\
\hline $22: 30$ & 21.2 & 31.5 & Night & Night & 8.48 & 0.32 & 3.3 & 0.3 & 96.0 & 1.0 \\
\hline $02: 30$ & 21.2 & 31.5 & Night & Night & 8.52 & 0.24 & 3.3 & 0.6 & 85.8 & 7.5 \\
\hline $06: 30$ & 21.3 & 31.5 & 2990 & 0.56 & 9.50 & 0.28 & 2.9 & 0.8 & 94.6 & 7.9 \\
\hline $10: 30$ & 21.3 & 31.5 & 2210 & 0.54 & 10.22 & 0.25 & 3.6 & 0.7 & 91.1 & 11.7 \\
\hline \multicolumn{11}{|l|}{ Sep 2008} \\
\hline 07:00 & 22.8 & 30.7 & 1727 & 0.7 & 13.18 & 0.73 & 6.3 & 0.8 & 191.4 & 14.2 \\
\hline $11: 00$ & 23.2 & 30.8 & 2160 & 0.69 & 13.73 & 0.64 & 4.4 & 0.8 & 115.6 & 4.3 \\
\hline $15: 00$ & 23.3 & 30.8 & 1360 & 0.64 & 14.02 & 0.18 & 1.2 & 0.2 & 235.0 & 16.2 \\
\hline $19: 00$ & 23.5 & 30.8 & Night & Night & 12.48 & 0.55 & 3.9 & 0.1 & 289.9 & 19.0 \\
\hline $23: 00$ & 23.2 & 30.7 & Night & Night & 13.13 & 0.16 & 4.7 & 0.7 & 249.3 & 7.2 \\
\hline 03:00 & 23.1 & 30.7 & Night & Night & 12.43 & 0.06 & 5.7 & 0.2 & 396.5 & 3.6 \\
\hline 07:00 & 23.1 & 30.6 & 630 & 0.73 & 14.48 & 0.50 & 6.9 & 0.2 & 240.5 & 12.4 \\
\hline $11: 00$ & 23.8 & 30.4 & 1460 & 0.66 & 14.80 & 0.48 & 6.2 & 0.2 & 303.6 & 11.7 \\
\hline $15: 00$ & 23.4 & 30.4 & 270 & 0.63 & 15.60 & 0.65 & 6.5 & 0.1 & 199.4 & 12.5 \\
\hline
\end{tabular}

Table 2. Relative abundance of major bacterial clades examined in this study during the 3 cruises in Delaware coastal waters, given as \% of total sequences. Sampling between 19:00 and 02:30 h was at night (table continues on next page)

\begin{tabular}{|c|c|c|c|c|c|c|c|}
\hline May 2007 cruise & $\begin{array}{l}\text { Day } 1 \\
09: 00\end{array}$ & $\begin{array}{l}\text { Day } 1 \\
13: 00\end{array}$ & $\begin{array}{l}\text { Day } 1 \\
21: 00\end{array}$ & $\begin{array}{l}\text { Day } 2 \\
01: 00\end{array}$ & $\begin{array}{l}\text { Day } 2 \\
09: 00\end{array}$ & Average & $\mathrm{SD}$ \\
\hline SAR11 & 34.6 & 35.6 & 36.8 & 41.3 & 39.2 & 37.1 & 3.0 \\
\hline Other Alphaproteobacteria & 14.0 & 13.4 & 15.5 & 13.1 & 15.3 & 14.0 & 1.1 \\
\hline SAR86 & 12.3 & 10.7 & 11.7 & 10.8 & 10.6 & 11.4 & 0.8 \\
\hline Other Gammaproteobacteria & 3.5 & 4.2 & 3.6 & 3.1 & 2.5 & 3.6 & 0.5 \\
\hline Bacteroidetes & 9.4 & 10.1 & 9.4 & 8.3 & 12.3 & 9.3 & 0.7 \\
\hline Cyanobacteria & 0.7 & 0.9 & 1.0 & 0.6 & 6.9 & 0.8 & 0.2 \\
\hline Actinobacteria & 7.9 & 6.4 & 6.9 & 7.9 & 1.2 & 7.3 & 0.8 \\
\hline Other groups & 17.6 & 18.7 & 15.1 & 14.9 & 12.0 & 16.6 & 1.9 \\
\hline Sep 2007 cruise & $\begin{array}{c}\text { Day } 1 \\
10: 30\end{array}$ & $\begin{array}{c}\text { Day } 1 \\
14: 30\end{array}$ & $\begin{array}{l}\text { Day } 1 \\
22: 30\end{array}$ & $\begin{array}{l}\text { Day } 2 \\
02: 30\end{array}$ & & Average & $\mathrm{SD}$ \\
\hline SAR11 & 37.2 & 32.9 & 38.2 & 29.0 & & 34.3 & 4.2 \\
\hline Other Alphaproteobacteria & 11.7 & 14.6 & 14.6 & 12.7 & & 13.4 & 1.4 \\
\hline SAR86 & 7.5 & 7.3 & 8.6 & 11.5 & & 8.7 & 1.9 \\
\hline Other Gammaproteobacteria & 4.2 & 4.2 & 4.3 & 4.4 & & 4.3 & 0.1 \\
\hline Bacteroidetes & 6.8 & 11.4 & 9.2 & 9.9 & & 9.3 & 1.9 \\
\hline Cyanobacteria & 13.8 & 13.2 & 7.6 & 12.2 & & 11.7 & 2.8 \\
\hline Actinobacteria & 9.6 & 7.7 & 8.0 & 8.5 & & 8.5 & 0.8 \\
\hline Other groups & 9.2 & 8.7 & 9.5 & 11.8 & & 9.8 & 1.4 \\
\hline
\end{tabular}


Table 2 (continued)

\begin{tabular}{|c|c|c|c|c|c|c|c|}
\hline Sep 2008 cruise & $\begin{array}{l}\text { Day } 1 \\
07: 00\end{array}$ & $\begin{array}{c}\text { Day } 1 \\
11: 00\end{array}$ & $\begin{array}{l}\text { Day } 1 \\
19: 00\end{array}$ & $\begin{array}{l}\text { Day } 1 \\
23: 00\end{array}$ & $\begin{array}{l}\text { Day } 2 \\
07: 00\end{array}$ & Average & $\mathrm{SD}$ \\
\hline SAR11 & 33.8 & 31.8 & 23.5 & 37.4 & 27.2 & 31.6 & 5.9 \\
\hline Other Alphaproteobacteria & 16.2 & 16.6 & 17.2 & 16.4 & 13.9 & 16.6 & 0.4 \\
\hline SAR86 & 11.0 & 13.0 & 12.1 & 8.8 & 8.3 & 11.2 & 1.8 \\
\hline Other Gammaproteobacteria & 2.6 & 2.8 & 2.5 & 1.7 & 5.2 & 2.4 & 0.5 \\
\hline Bacteroidetes & 14.9 & 14.4 & 14.9 & 18.3 & 10.4 & 15.6 & 1.8 \\
\hline Cyanobacteria & 6.8 & 8.7 & 12.1 & 5.7 & 13.0 & 8.3 & 2.8 \\
\hline Actinobacteria & 2.1 & 1.4 & 2.2 & 1.5 & 8.6 & 1.8 & 0.4 \\
\hline Other groups & 12.6 & 11.3 & 15.5 & 10.2 & 13.4 & 12.6 & 2.3 \\
\hline
\end{tabular}

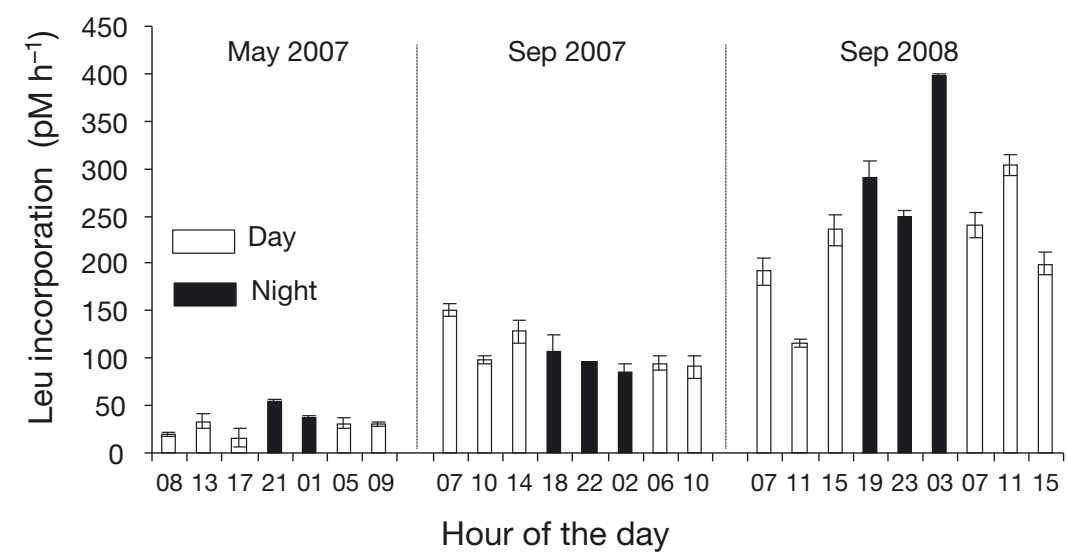

Fig. 1. Leucine incorporation during the 3 cruises conducted in Delaware coastal waters ( \pm SD from technical triplicates)

also abundant, varying between about $9 \%$ (September 2007) and $11 \%$ (May). Cyanobacteria varied from $0.8 \%$ of all $16 \mathrm{~S}$ rRNA sequences in May 2007 to $11.7 \%$ in September 2007 (Table 2). Actinobacteria, another abundant group in Delaware coastal waters, made up $7.3 \%$ in May and 8.5\% in September 2007, but only $1.8 \%$ in September 2008 (Table 2). Rarefaction curves showed that our sequencing effort recovered about $65 \%$ of the total diversity (data not shown).

\section{Expression of PR and 16S rRNA genes}

The relative expression of SAR11 PR genes varied over the day-night cycle during the 3 cruises (Fig. 3). During the May cruise, the transcript to gene ratios of SAR11 PR genes (SAR11 PR mRNA:DNA ratio) peaked at 09:00 $\mathrm{h}$ both on Day 1 (ratio of $1.5 \pm 0.1$ ) and Day 2 ( $3 \pm 0.03)$. Expression was slightly lower at 13:00 h (ratio of $1.3 \pm 0.05$ ). During all other hours of this cruise, the relative expression of SAR11 PR genes was very low (mRNA:DNA < 0.3) (Fig. 3A). In September 2007, a similar pattern was observed
(Fig. 3B). The SAR11 PR mRNA:DNA ratio peaked at $10: 30 \mathrm{~h}$ on Day 1 (2.4 \pm 0.1 ) and Day $2(2.5 \pm 0.04)$. The relative expression at other times was lower, remaining below 0.75 during the day and night. In September 2008, the relative expression of SAR11 PR was again higher during the day than during the night (Fig. 3C). The relative expression was highest at 11:00 h during Day 1 (ratio $1.4 \pm 0.3$ ) and at 15:00 h during Day 2 (1.5 \pm 0.03). During the night, SAR11 PR mRNA:DNA ratios were <0.6. Most of the change in the SAR11 PR ratios was due to changes in mRNA. During each cruise, PR gene abundance varied 3-fold, while PR mRNA concentration varied 7 -fold (data not shown).

To compare changes in PR and $16 \mathrm{~S}$ rRNA ratios, the data from all 3 cruises were combined and averages ( $\pm \mathrm{SE}$ ) were calculated for day and night (Fig. 4). During the 3 cruises, SAR11 PR mRNA:DNA ratios differed between day and night, but the ratio for SAR11 16S rRNA genes (16S rRNA:rDNA) did not (Fig. 4). The SAR11 PR mRNA:DNA ratio was 2.5fold higher during the day $(1.30 \pm 0.30)$ than at night $(0.46 \pm 0.05)$. The difference was statistically significant (Student's $t$-test, $\mathrm{p}<0.05$ ). In contrast, the SAR11 16S rRNA:rDNA ratio did not change significantly between day $(54 \pm 15)$ and night $(52 \pm 8)$. The total bacterial 16S rRNA:rDNA ratio also did not vary significantly between day and night (Fig. 4).

\section{Correlations between transcript to gene ratios and environmental parameters}

The transcript to gene ratio for SAR11 PR and SAR11 16S rRNA varied about 30-fold and 20-fold, 


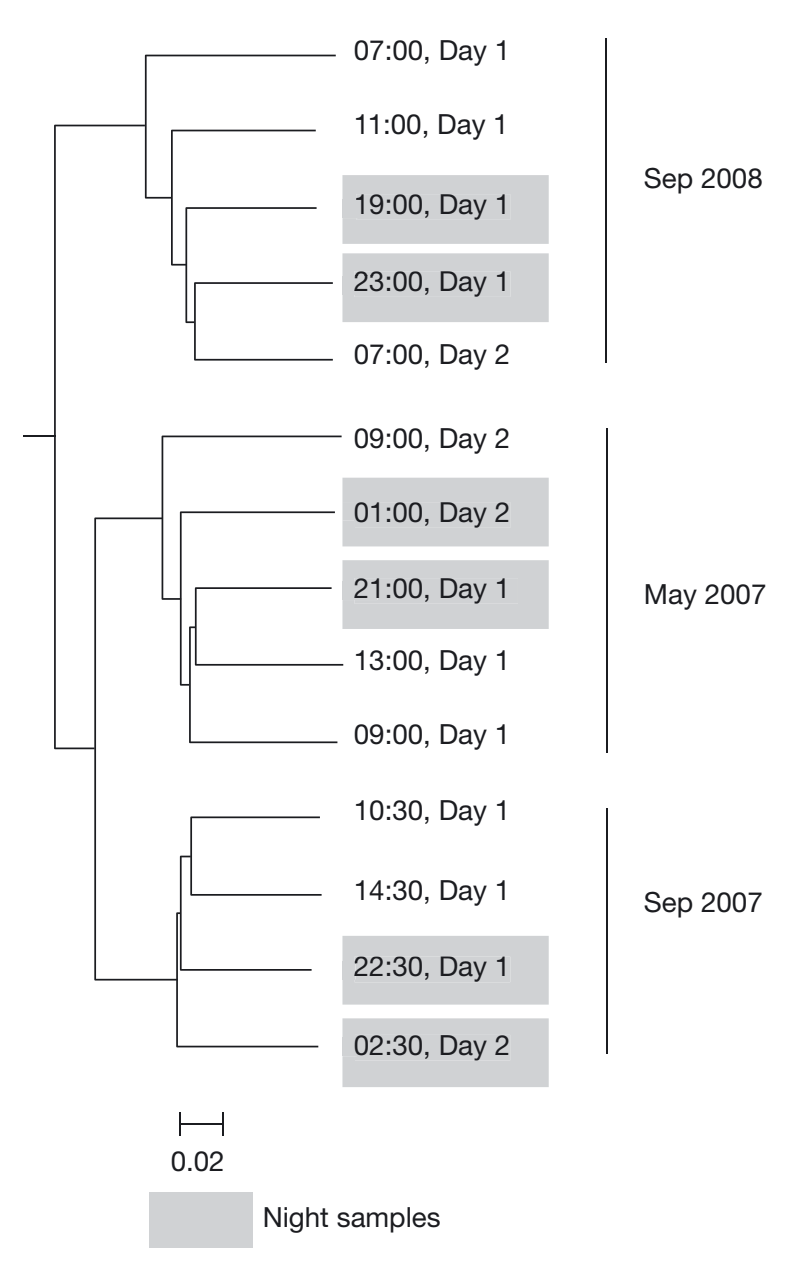

Fig. 2. UPGMA clustering of total bacterial communities defined by pyrosequences of $16 \mathrm{~S}$ rRNA genes $197 \%$ of sequence similarity). Samples collected during the night are indicated with a gray background

respectively, but we did not find any significant correlation between the 2 ratios (Pearson's correlation coefficient, $\mathrm{r}=0.3, \mathrm{p}>0.05, \mathrm{n}=24$ ) (Fig. 5A). The relationship between SAR11 PR genes and total bacterial 16S rRNA genes was also not significant $(\mathrm{r}=$ $0.2, \mathrm{p}>0.05, \mathrm{n}=24$, data not shown). However, there was a significant relationship between SAR11 16S rRNA:rDNA and the total bacterial 16S rRNA:rDNA ratio $(\mathrm{r}=0.89, \mathrm{p}<0.01, \mathrm{n}=24)$ (Fig. 5B).

There was also a significant relationship between PAR and the mRNA:DNA ratio for SAR11 PR, excluding the night data $(\mathrm{r}=0.66, \mathrm{p}<0.05 \mathrm{n}=15)$. In contrast, no significant correlation was found between the measured environmental parameters and the SAR11 PR mRNA:DNA ratios $(\mathrm{r}=0.1$ to $0.4, \mathrm{p}>0.05$, $\mathrm{n}=24$; data not shown).
A) May 2007
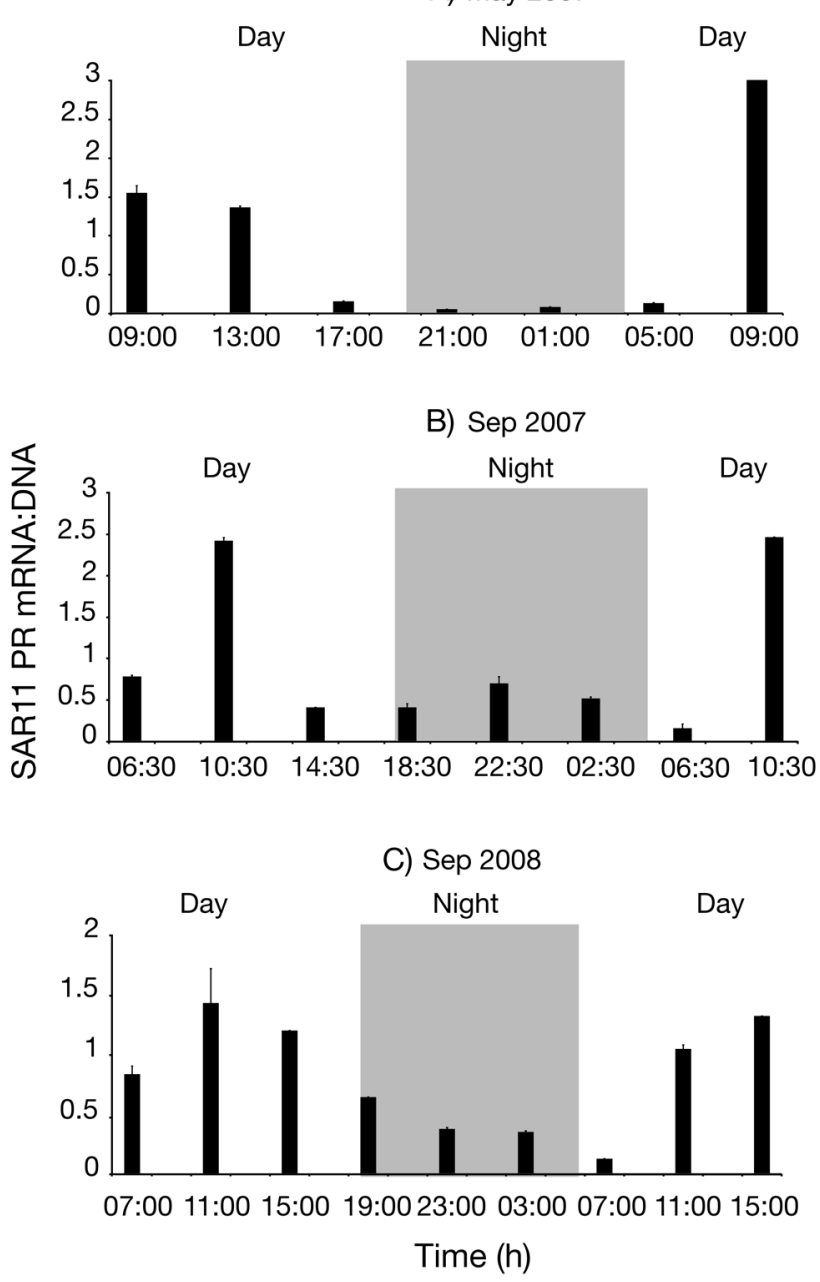

Fig. 3. SAR11 proteorhodopsins (PR) mRNA:DNA ratio $( \pm \mathrm{SE}$ from technical triplicates) over time in (A) May 2007, (B) September 2007 and (C) September 2008. Samples collected during the night are indicated with a gray background

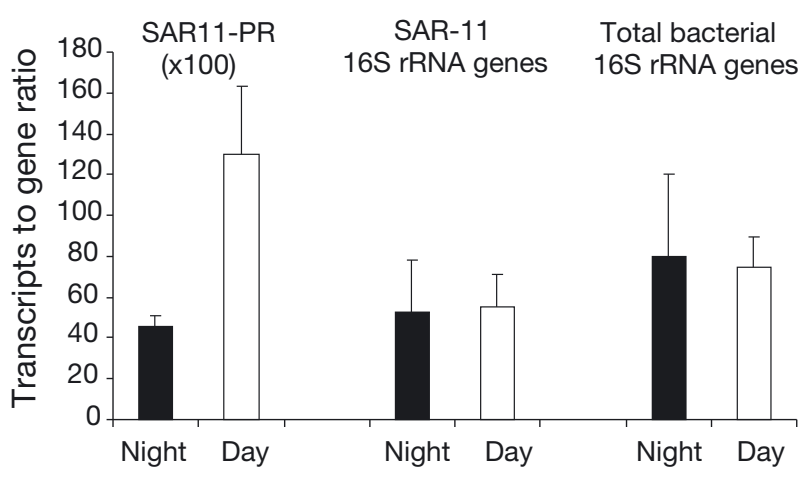

Fig. 4. Averages $( \pm \mathrm{SE})$ of transcript to gene ratios for SAR11 proteorhodopsins (PR) $(\times 100)$, SAR11 16S rRNA and total bacterial 16S rRNA during day and night in Delaware coastal waters. The data are from all 3 cruises 

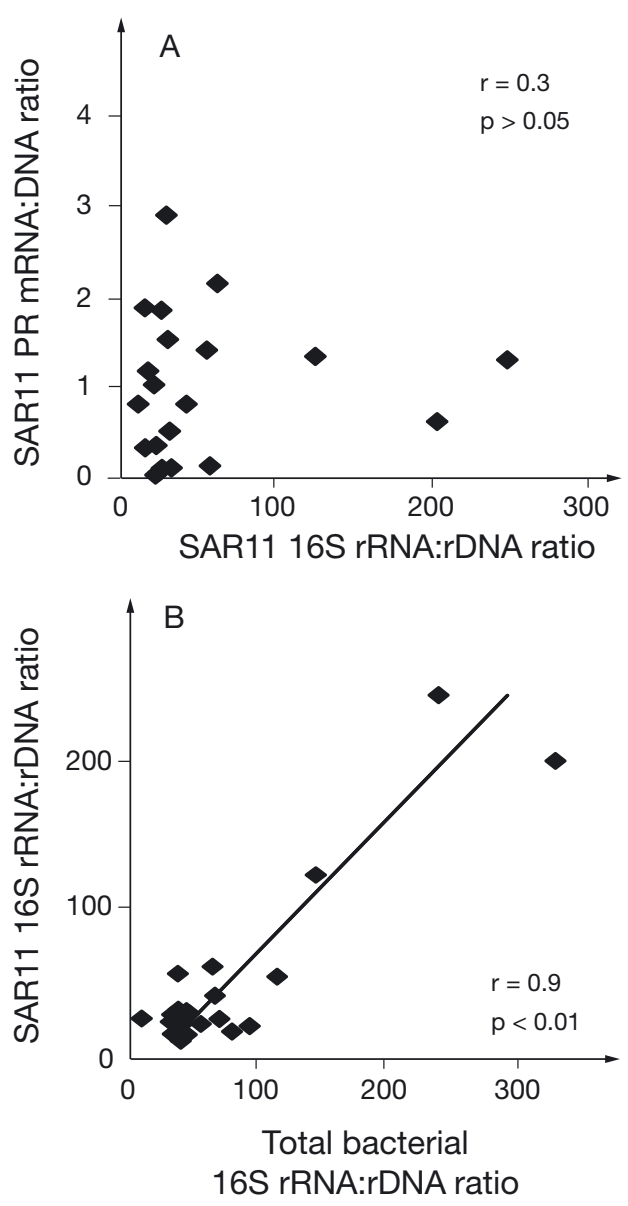

Fig. 5. (A) Relationship between the SAR11 proteorhodopsins (PR) mRNA:DNA ratio and the SAR11 16S rRNA:16S rDNA ratio. (B) Relationship between the SAR11 16S rRNA: rDNA ratio and the total bacterial 16S rRNA:rDNA ratio

\section{DISCUSSION}

In this study, we examined patterns of PR expression by the widespread SAR11 bacterial clade during 3 cruises in Delaware coastal waters. We found that the relative expression of SAR11 PR was about 2.5fold higher during the day than at night and that the relative PR expression was modulated by the amount of PAR. Our experiment supports the existence of a tight relationship between light and relative PR expression in marine SAR11 bacteria, but there was no relationship between PR expression and 16S rRNA:rDNA ratios.

These field data are consistent with previous studies demonstrating higher PR expression with light in microcosm experiments with natural bacterial communities (Lami et al. 2009a) and pure culture experiments with the flavobacterial strain Dokdonia (Gómez-
Consarnau et al. 2007, Kimura et al. 2011). In contrast, expression of PR by Candidatus Pelagibacter ubique HTCC1062, a cultivated representative member of the SAR11 clade, is higher in the dark than in the light (Steindler et al. 2011). This Candidatus P. ubique strain may not be representative of SAR11 strains found in Delaware coastal waters; it is well known that the SAR11 clade is phylogenetically and functionally diverse (Wilhelm et al. 2007). This diversity may explain the differences observed between PR expression by the Candidatus Pelagibacter strain in culture and by SAR11 cells in Delaware coastal waters. It also highlights the need for experiments with natural communities, such as those discussed here, and to integrate results from those experiments with appropriate data from lab experiments with model organisms.

Tides and coastal currents potentially complicate our interpretation of the temporal patterns in genes and transcription described in this study. However, several observations lead us to conclude that tides and currents do not explain the diel variation in the relative PR expression we observed. Physical and chemical data showed that variations between cruises were much larger than variations within a cruise. In spite of this variation, the influence of light on SAR11 PR and SAR11 16S rRNA transcription was similar during all 3 cruises in all 3 seasons. Clustering of total 16S rRNA gene sequences indicated that the bacterial community composition was highly similar in the water masses sampled during a single cruise. Even if communities varied among the water masses we sampled during a cruise, they appeared to respond similarly to daylight variations. We suspect that a similar physiological response to light occurred in all the SAR11 communities we sampled in Delaware coastal waters.

A key question addressed in this work is whether the expression of PR fuels growth-related activity of SAR11 bacteria in coastal waters. In this study, we used the relative expression level of 16S rRNA genes as a measure of this aspect of bacterial activity, an approach based on the relationship between rRNA levels per cell and growth rates and between rRNA synthesis and protein synthesis in pure cultures (see review by Blazewicz et al. 2013). Several previous studies have used this relationship to explore growth-based activity in natural communities (Blazewicz et al. 2013). In particular, Campbell et al. (2012) used 16S rRNA:rDNA ratios to monitor SAR11 growthrelated activity as a function of several environmental variables at the same Delaware site as this study. We did not see a significant relationship between $16 \mathrm{~S}$ 
rRNA:rDNA and PR mRNA:DNA for SAR11, suggesting that energy from PR did not substantially affect SAR11 growth-related activity.

The lack of an obvious coupling between PR expression and the 16S rRNA:rDNA ratio for SAR11 is consistent with the theoretical calculations of Kirchman \& Hanson (2013), who suggested that the amount of energy provided by PR is small compared with the energy required for bacterial growth. It would be difficult to detect a small contribution, especially with natural microbial communities. Light appears to enhance uptake of methionine and ATP by SAR11 cells in the North Atlantic Ocean by about $30 \%$ on average (Gómez-Pereira et al. 2013), which is more than predicted by theoretical calculations (Kirchman \& Hanson 2013), but still near the detection limits of many methods. This level of enhancement may be too small to detect with 16S rRNA:rRNA ratios, especially if there is uncoupling between 16S rRNA synthesis and growth. Levels of 16S rRNA would also likely not capture any enhanced survival of bacteria due to $\mathrm{PR}$, as observed for Candidatus P. ubique (Steindler et al. 2011). Light-enhanced survival of bacteria probably does not depend on enhanced protein synthesis and thus would not likely be detectable with $16 \mathrm{~S}$ rRNA data.

Other environmental conditions have recently been shown to upregulate PR expression, but some of these conditions are likely not found in coastal waters, while others lead to a prediction opposite from the observed results. These conditions include the transition from the exponential to stationary phase and energy limitation caused by respiratory stress, both of which lead to higher PR expression in various cultivated bacteria (Gómez-Consarnau et al. 2010, Akram et al. 2013). In contrast to the laboratory studies, we sampled well oxygenated, mesotrophic coastal waters where bacteria likely grow continuously without respiratory stress. While bacterial growth is likely limited by organic carbon in these waters, the laboratory experiments showing higher PR expression during energy limitation would lead us to expect PR expression to be lower, not higher during the day, when release of labile organic material from phytoplankton is thought to be highest (Nagata 2000). Thus, an indirect effect of light on SAR11 PR expression appears unlikely.

The complicated relationships among PR, bacterial growth and light have implications for understanding diel patterns in heterotrophic bacterial properties. Although diel patterns in cyanobacteria are well known (Vaulot et al. 1995), they are less clear cut for other members of the bacterioplanktonic community.
Some studies have not found diel patterns in the incorporation of thymidine, leucine or bromodeoxyuridine (Riemann \& Søndergaard 1984, Torreton \& Dufour 1996, Gasol et al. 1998, Pernthaler \& Pernthaler 2005). Other studies, however, have shown an effect of solar radiation on diel cycles of thymidine and leucine incorporation (Jeffrey et al. 1996, RuizGonzález et al. 2012a), bacterial division deduced from $\mathrm{fts} Z$ expression (Yao et al. 2011) and recA gene expression (Booth et al. 2001) by natural bacterial communities. The inconsistency in diel patterns for bacterial communities may in part result from variation in bacterial community composition and in how different PR-bearing bacteria respond to light. Communities with a large number of Flavobacteria may be more responsive to light than those dominated by SAR11, based on the documented light effects on PRbearing Flavobacteria versus cultured representative members of the SAR11 group.

Our field data indicate light-dependent expression of PR genes by SAR11 bacteria in natural microbial communities. These in situ data contribute to the debate about the relationship between light, activity and PR expression, which has been examined so far with microcosm or culture-based experiments. These results highlight the need to better understand and characterize the role of PR in microbial physiology and oceanography.

Acknowledgements. We thank the crew of the R/V 'Hugh R. Sharp', Matthew T. Cottrell and members of the Kirchman lab for help in sampling and collecting environmental parameters. This work was supported by NSF OCE-0825468 and 1030306 and by a Partner University Grant.

\section{LITERATURE CITED}

Akram N, Palovaara J, Forsberg J, Lindh MV and others (2013) Regulation of proteorhodopsin gene expression by nutrient limitation in the marine bacterium Vibrio sp. AND4. Environ Microbiol 15:1400-1415

Béjà O, Aravind L, Koonin EV, Suzuki MT and others (2000) Bacterial rhodopsin: evidence for a new type of phototrophy in the sea. Science 289:1902-1906

Blazewicz SJ, Barnard RL, Daly RA, Firestone MK (2013) Evaluating rRNA as an indicator of microbial activity in environmental communities: limitations and uses. ISME J 7:2061-2068

> Booth MG, Jeffrey WH, Miller RV (2001) RecA expression in response to solar UVR in the marine bacterium Vibrio natriegens. Microb Ecol 42:531-539

Campbell BJ, Kirchman DL (2012) Bacterial diversity, community structure and potential growth rates along an estuarine salinity gradient. ISME J 7:210-220

Campbell BJ, Waidner LA, Cottrell MT, Kirchman DL (2008) Abundant proteorhodopsin genes in the North Atlantic Ocean. Environ Microbiol 10:99-109 
Campbell BJ, Yu L, Heidelberg JF, Kirchman DL (2011) Activity of abundant and rare bacteria in a coastal ocean. Proc Natl Acad Sci USA 108:12776-12781

Caporaso JG, Kuczynski J, Stombaugh J, Bittinger K and others (2010) QIIME allows analysis of high-throughput community sequencing data. Nat Methods 7:335-336

Cottrell MT, Mannino A, Kirchman DL (2006) Aerobic anoxygenic phototrophic bacteria in the Mid-Atlantic Bight and the North Pacific Gyre. Appl Environ Microbiol 72:557-564

de la Torre JR, Christianson LM, Béjà O, Suzuki MT, Karl DM, Heidelberg J, DeLong EF (2003) Proteorhodopsin genes are distributed among divergent marine bacterial taxa. Proc Natl Acad Sci USA 100:12830-12835

> Dempster EL, Pryor KV, Francis D, Young JE, Rogers HJ (1999) Rapid DNA extraction from ferns for PCR-based analyses. Biotechniques 27:66-68

> Feng S, Powell SM, Wilson R, Bowman JP (2013) Light stimulated growth of proteorhodopsin-bearing sea-ice psychrophile Psychroflexus torquis is salinity dependent. ISME J 7:2206-2213

> Finkel OM, Béjà O, Belkin S (2013) Global abundance of microbial rhodopsins. ISME J 7:448-451

Fuhrman JA, Schwalbach MS, Stigl U (2008) Proteorhodopsins: an array of physiological roles? Nat Rev Microbiol 6:488-494

> Gasol JM, Doval MD, Pinhassi J, Caderon-Paz JI, GuixaBoixareu N, Vaqué D, Pedrós-Alió C (1998) Diel variations in bacterial heterotrophic activity and growth in the northwestern Mediterranean Sea. Mar Ecol Prog Ser 164:107-124

Giovannoni SJ, Bibbs L, Cho JC, Stapels MD and others (2005) Proteorhodopsin in the ubiquitous marine bacterium SAR11. Nature 438:82-85

Gómez-Consarnau L, González JM, Coll-Lladó M, Gourdon $P$ and others (2007) Light stimulates growth of proteorhodopsin-containing marine Flavobacteria. Nature 445:210-213

Gómez-Consarnau L, Akram N, Lindell K, Pedersen A and others (2010) Proteorhodopsin phototrophy promotes survival of marine bacteria during starvation. PLoS Biol 8:e1000358

> Gómez-Pereira PR, Hartmann M, Grob C, Tarran GA and others (2013) Comparable light stimulation of organic nutrient uptake by SAR11 and Prochlorococcus in the North Atlantic subtropical gyre. ISME J 7:603-614

> Jeffrey WH, Pledger RJ, Aas P, Hager S Coffin RB, Von Haven R, Mitchell DL (1996) Diel and depth profiles of DNA photodamage in bacterioplankton exposed to ambient solar ultraviolet radiation. Mar Ecol Prog Ser 137:283-291

Kimura H, Young CR, Martinez A, DeLong EF (2011) Lightinduced transcriptional responses associated with proteorhodopsin-enhanced growth in a marine flavobacterium. ISME J 5:1641-1651

> Kirchman DL, Hanson TE (2013) Bioenergetics of photoheterotrophic bacteria in the oceans. Environ Microbiol Rep 5:188-199

> Lami R, Cottrell MT, Campbell BJ, Kirchman DL (2009a) Light-dependent growth and proteorhodopsin expression by Flavobacteria and SAR11 in experiments with Delaware coastal waters. Environ Microbiol 11: 3201-3209

> Michelou VK, Cottrell MT, Kirchman DL (2007) Light-stimulated bacterial production and amino acid assimilation by cyanobacteria and other microbes in the North Atlantic Ocean. Appl Environ Microbiol 73:5539-5546

> Morris RM, Rappé MS, Connon SA, Vergin KL and others (2002) SAR11 clade dominates ocean surface bacterioplankton communities. Nature 420:806-810

Nagata T (2000) Production mechanisms of dissolved organic matter. In: Kirchman DL (ed) Microbial ecology of the oceans. Wiley Liss, New York, NY, p 121-152

> Ottesen EA, Young CR, Eppley JM, Ryan JP, Chavez FP, Scholin CA, DeLong EF (2013) Pattern and synchrony of gene expression among sympatric marine microbial populations. Proc Natl Acad Sci USA 110:E488-E497

Pernthaler A, Pernthaler J (2005) Diurnal variation of cell proliferation in three bacterial taxa from coastal North Sea waters. Appl Environ Microbiol 71:4638-4644

Poretsky RS, Hewson I, Sun S, Allen AE, Zehr JP, Moran MA (2009) Comparative day/night metatranscriptomic analysis of microbial communities in the North Pacific subtropical gyre. Environ Microbiol 11:1358-1375

Quince C, Lanzen A, Curtis TP, Davenport RJ and others (2009) Accurate determination of microbial diversity from 454 pyrosequencing data. Nat Methods 6:639-641

> Riedel T, Tomasch J, Buchholz I, Jacobs J and others (2010) Constitutive expression of the proteorhodopsin gene by a Flavobacterium strain representative of the proteorhodopsin producing microbial community in the North Sea. Appl Environ Microbiol 76:3187-3197

> Riemann B, Søndergaard M (1984) Measurements of diel rates of bacterial secondary production in aquatic environments. Appl Environ Microbiol 47:632-638

> Ruiz-González C, Lefort T, Massana R, Simo R, Gasol JM (2012a) Diel changes in bulk and single-cell bacterial heterotrophic activity in winter surface waters of the northwestern Mediterranean Sea. Limnol Oceanogr 57: $29-42$

Ruiz-González C, Lefort T, Galí M, Montserrat Sala M, Sommaruga R, Simó R, Gasol JM (2012b) Seasonal patterns in the sunlight sensitivity of bacterioplankton from Mediterranean surface coastal waters. FEMS Microbiol Ecol 79:661-674

> Rusch DB, Halpern AL, Sutton G, Heidelberg KB and others (2007) The Sorcerer II Global Ocean Sampling expedition: northwest Atlantic through eastern tropical Pacific. PLoS Biol 5:e77

> Steindler L, Schwalbach MS, Smith DP, Chan F, Giovannoni SJ (2011) Energy starved Candidatus Pelagibacter ubique substitutes light-mediated ATP production for endogenous carbon respiration. PLoS ONE 6:e19725

Stingl U, Desiderio RA, Cho JC, Vergin KL, Giovannoni SJ (2007) The SAR92 clade: an abundant coastal clade of culturable marine bacteria possessing proteorhodopsin. Appl Environ Microbiol 73:2290-2296

> Straza TRA, Kirchman DL (2011) Single-cell response of bacterial groups to light and other environmental factors in the Delaware Bay, USA. Aquat Microb Ecol 62: $267-277$

Torreton JP, Dufour P (1996) Temporal and spatial stability of bacterioplankton biomass and productivity in an atoll lagoon. Aquat Microb Ecol 11:251-261

> Vaulot D, Marie D, Olson RJ, Chisholm SW (1995) Growth of Prochlorococcus, a photosynthetic prokaryote, in the equatorial Pacific Ocean. Science 268:1480-1482

> Venter JC, Remington K, Heidelberg JF, Halpern AL and others (2004) Environmental genome shotgun sequencing of the Sargasso Sea. Science 304:66-74 
Walter JM, Greenfield D, Bustamante C, Liphardt J (2007) Light-powering Escherichia coli with proteorhodopsin. Proc Natl Acad Sci USA 104:2408-2412

Wang Z, O'Shaughnessy TJ, Soto CM, Rahbar AM, Robertson KL, Lebedev N, Vora GJ (2012) Function and regulation of Vibrio campbellii proteorhodopsin: acquired phototrophy in a classical organoheterotroph. PLoS ONE 7: e38749

Editorial responsibility: Ruben Sommaruga, Innsbruck, Austria
Wilhelm LJ, Tripp HJ, Givan SA, Smith DP, Giovannoni SJ (2007) Natural variation in SAR11 marine bacterioplankton genomes inferred from metagenomic data. Biol Direct 2:27

Yao D, Buchan A, Suzuki MT (2011) In situ activity of NAC11-7 roseobacters in coastal waters off the Chesapeake Bay based on $\mathrm{fts} Z$ expression. Environ Microbiol 13:1032-1041

Submitted: January 23, 2014; Accepted: July 23, 2014

Proofs received from author(s): September 29, 2014 